\title{
THE IMPORTANCE OF SUSTAINABLE RURAL TOURISM DEVELOPMENT IN SERBIA
}

\author{
Milena Podovac ${ }^{1}$, \\ Melita Jovanović Tončev² \\ ${ }^{1}$ University of Kragujevac, \\ Faculty of Hotel Management and \\ Tourism in Vrnjačka Banja, \\ Vrnjačka Banja, Serbia \\ ${ }^{2}$ Singidunum University, \\ 32 Danijelova Street, Belgrade, Serbia
}

\begin{abstract}
:
Tourism largely exploites resources that are not renewable. Due to the mass tourist travel destinations, the environment suffers negative consequences of such development. All these reasons cause the development of sustainable forms of tourism, in those aspects which do not cause the pollution of nature and its resources. The implementation of the concept of sustainable development of rural tourism has ensured that this form of tourism has nowdays become specific market niche, which attrackts tourists to spend time in rural environment. Rural tourism contributes to the revitalization of the village through the involvement of rural households in the provision of services to tourists, marketing of agricultural products on the tourist market as well as the promotion of cultural heritage and traditions of the village. The potential of rural tourism is also reflected in the preservation of natural resources.

This paper analyzes the current situation of rural tourism of the Republic of Serbia with an emphasis on the examples of good practice. With the aim of emphasizing the opportunities for further development, the authors disclose the example of rural tourism destinations in Serbia. In the concluding remarks, guidelines for improving the existing rural tourism supply in Serbia are provided.
\end{abstract}

Key words:

rural tourism, sustainability, development, Republic of Serbia.

\section{INTRODUCTION}

The concept of development based on the principles of sustainability emerged in the early 90's of the 20th century, in response to the need to establish a balance between the uncontrolled and unplanned development. This development has resulted in the disruption of the Earth's eco-system, as well as the resources necessary for the cited development, and therefore the whole of human society. Due to the synergetic effect of economic, environmental, social, cultural and other dimensions of sustainable development, it was necessary to create an integrated approach that would have complied with all of these components based on the principles of sustainability. From this point of view, it could be said that sustainable development represents an integral economic, technological, socio-cultural development, in line with the needs of safeguard, protection and improvement of the environment, which enables current and future generations to meet the needs and improve the quality of life [12]. The link could be observed between sustainable development and tourism as an 
industry that recorded the highest level of development in the 20th and at the beginning of 21st century and sustainable development is more than obvious. Development of tourism uses and gradually destroys the natural resources which essentially constitute the basis for its further development. So, if tourism would be developed on the principles of sustainability and responsible behaviour towards the resources used in this way it would protect the base for further development. According to the simplest definition, rural tourism is defined as any form of tourism that takes place in the countryside [1]. By staying in the village, tourists enjoy the natural environment; they're engaged in activities typical of rural areas and learn about the culture and traditions of the community being in contact with the population. In this sense, rural tourism contributes to the revitalization in the economic, ecological and socio-cultural sense with the aim of improving the status and life standard of local inhabitants. In this paper, the authors give the analysis of the importance of sustainability for development of rural tourism in the Republic of Serbia through the theoretical analysis and presentation of examples of good practices.

\section{SUSTAINABLE TOURISM}

Abandoning the concept of tourism development solely on economic basis, which included the attainment of greater profit, many world tourist destinations are starting to apply the concept of development, which implies respect for social, environmental and cultural interests of receiving countries. It is concerned with the socially responsible tourism development, which involves meeting the needs of tourists and creation of profit and delivering value for money, but also the establishment of corporate social responsibility in business. The literature often defines sustainable tourism as a positive approach seeking to reduce tensions that are the result of complex interactions between the tourism industry, visitors, environment and society as a host [2]. The impact of tourism on the environment of the host countries can be positive and negative. Positive effects include: renewal and restoration of existing historical sites, buildings and monuments, transformation of the existing old buildings and places in tourism facilities, protection of natural resources, adoption of various administrative and planning measures for the protection of certain areas, improving the availability of space and creation of new tourist areas, building environmental awareness and the like [2]. However, uncontrolled and non-strategic tourism development in the particular area may have negative effects such as: pollution of the area due to the construction of tourist facilities and equipment, pollution of air, water, soil, noise pollution, depletion of natural and agricultural areas, destruction of flora and fauna, degradation of the landscape, as well as historical and cultural monuments, cluttering of space, geological forms of degradation, spatial redistribution of the population and generalization of space [4].

In order to minimize the negative effects of tourism development of specific destinations and maximize the positive ones, it is necessary to establish the balance between the needs of visitors, the tourism industry, the environment and local communities [22]. In order to establish the mentioned balance, it is essential that the sustainable tourism [21]:

- makes optimum use of to environmental resources that constitute a key element in tourism development, maintaining essential ecological processes and helping to preserve the natural heritage and biodiversity,

- respects the socio-cultural authenticity of host communities, protects their built and modern cultural heritage and traditional values, and contributes to understanding and tolerance between cultures,

- provides sustainable long-term business, creating socio-economic benefits, which is fairly distributed to all stakeholders, including stable employment, opportunities for income generation and welfare of host communities, as well as contributing to poverty reduction,

- sustains a high level of tourist satisfaction enabling them to acquire unique experience, developing their awareness about sustainability issues and promoting sustainable tourism.

Therefore, it is essential to apply strategically planned approaches to the use of natural resources at their disposal and simultaneously respect the tradition and culture of the local population, in order to achieve continuous tourism development. Establishing a balance between the need to get more profits and sustainability is the basic principle on which we should base the development of tourism in the 21st century.

\section{RURAL TOURISM AND THE CONCEPT OF SUSTAINABILLITY}

With the development of mass tourism travel and standardization of tourist's services, people have turned to natural, preserved and clean environment, such as rural 
areas in search of an authentic experience. The attraction of rural areas for tourists is connected with the possibility of satisfying needs for vacations, relaxation, activity holidays, gaining knowledge about the way of living in the country. The beginnings of development of the rural tourism are linked to the distant past when the privileged social class (the feudal lords, the bourgeoisie, the aristocracy) spent their leisure time in rural areas [20]. On the other hand, intensive development of tourism in rural areas is linked to the year 1970 in developed countries, which has contributed to the strengthening of villages in economic and social terms [16]. The fact that the development of rural tourism was intensified in the second half of the 20 th century points to the importance of this form of tourism for improve the status and existence of people who live in the countryside. The expansion of tourism in rural areas enabled [17]:

- creation and maintenance of local income, employment and growth,

- creation of resources for economic and social infrastructure,

- encouraging the development of the industrial sector,

- creation of local content and services,

- creation of conditions for the preservation of culture and cultural resources.

There are different interpretations of various forms of tourism in the literature. Difficulties in defining the concept of rural tourism are conditioned by the fact that it is very broad concept that includes not only a vacation in the countryside, but also all other tourist activities in rural areas [19]. Middleton assumes that rural tourism is recognized as synonymous for the good life, which is reflected in the fresh air, spending time in the natural environment and life in harmony with nature and the community [13]. Rural tourism can be defined as a vacation, during which tourists use most of their free time to deal with recreational activities on the farm, ranch, country or its surroundings [6]. Kušen analyzes the concept of tourism on family farms, which he considers a form of rural tourism that allows households in villages to expand their activities and increase the price of their products [10]. From the above it follows that the definition of rural tourism provides activities for tourists during their stay in the country, which has resulted in diversification of economic activities of rural households. Generally accepted definition implies that rural tourism includes a wide range of activities, services and additional contents that provide a host (farmers, peasants) on family farms and estates to attract tourists to their area in order to create additional income, respecting the principles of sustainable development and conservation of natural resources [15]. Modern tourism demand requires continuous innovation of rural tourism demand and development of new activities for tourists who want the full experience. Accordingly, the following forms have been identified [8]: agro-tourism, nature activities, eco-tourism, rural experience, cultural tourism and other forms of combination of special tourism interest. Difficulties in identifying forms of rural tourism are connected with the fact that this form of tourism has a lot in common with other forms of tourism. For example, villages, which have a rich culture and history, may, in their tourist offer activities include visits to sites of cultural and historical heritage, which let you create links between rural and cultural tourism.

The long-term successful development of rural tourism depends on the quality and availability of natural resources. Accordingly, the concept of sustainable development represents an indispensable segment of tourism development in rural areas. Sustainable rural tourism can be defined as an activity that contributes to positive economic and social development of rural areas and at the same time does not violate the social and natural environment [9]. Rural tourism is in correlation with the environment, as indicated by three basic characteristics [23]:

1. Low population density and relatively small size of settlement. For the definition of rural areas, it is important to observe and compare the potential tourists from the environment in which they live (usually urban) and characteristics of the certain area that make it rural. In this sense, rural areas with low population density and relatively small size of the settlement represent more pronounced attraction for tourists.

2. A way of land use and economic activity, that relies on agriculture, forestry and the use of raw materials. Depending on the differences between rural areas in terms of economic growth is determined by the attractiveness of these areas for potential tourists. Underdeveloped rural areas, which are relied on traditional agricultural small-case production, are more attractive to tourists, because they, among other things, seek to diversify development.

3. Traditionalism of social structures. Rural areas are characterized by a strong sense of community, local rather than cosmopolitan cultures and way of life that is slower, less materialistic and less complicated compared to urban areas. The growing interest of modern tourists for cultural heritage highlights the importance of these features of rural areas. 
The link between sustainable development and rural tourism is manifold. In the first place, tourism in rural areas provides livelihoods of the local population through job creation, encouraging public-private partnerships and boosting agricultural production. The development of tourism in rural areas improves the relationship between people of different demographic characteristics, respectively people from urban and rural areas. In this way, it is increasing the attractiveness of the local culture and traditions, in which the tourists are particularly interested. Benefits for rural areas are implemented through the interpretation of the environment. This is an activity, in which tourists are walking or driving along the roads, which are marked by certain information boards and signs and very often with information about the environment in order for tourists to gain some knowledge about the natural and cultural resources [7]. However, the concept of sustainability in rural tourism contributes to the realisation of multiple objectives [11]: preservation of local culture and character of the local community, preservation of natural landscapes and natural "habitat", sustainable development of rural economy, sustainable development of tourism industry in the long term, the development of understanding, leadership and vision of decision makers in the fields that they consider to be of danger for tourism and reliance of the same on them and continue to work towards achieving a balanced and diverse rural economy.

\section{EXAMPLES OF GOOD PRACTICE AND SUSTAINABLE RURAL TOURISM IN THE REPUBLIC OF SERBIA}

The Republic of Serbia is rich with resources for development of rural tourism on the principles of sustainability. Rural areas possess the high-quality natural resources, rich cultural and historical heritage, traditions, events, and all elements that are necessary for creation of an integrated offer in villages. However, the development of sustainable rural tourism is quite disorganized and characterized by the absence of public sector support in the legal, financial and institutional sense. Rural areas in Serbia cover $85 \%$ of the total territory, with $55 \%$ of the population, and achieve more than $40 \%$ of the total GDP [14]. Rural economy in Serbia is based on agricultural production with about $75 \%$ of the rural population engaged in agriculture, which creates conditions for the placement of agricultural products through tourism [3]. Serbia is rich in flora and fauna (428 protected animal and 215 protected plant species) and 1300 protected natural objects (5 national parks, 22 regional parks, 122 nature reserves, 375 natural monuments.) [17]. Numerous experts evaluated the situation in many rural areas of Serbia favorable for the environment, which is less burdened by chemical contamination and other waste. This, almost heretical, state brings the public into believing that the abandonment of the rural areas has its upper side. However, the truth is that the environment is burdened by different influences of the rural economy, depending on which part of the country is being observed. Intense pressure on the natural resources of agriculture in lowland areas results in depletion soil, and highly contaminated surface water and groundwater. The risk of pollution of water sources can be degreased by reducing the use of species of fertilizers in marginal mountain areas. On the other hand, complete abandonment of the application of agricultural technology can contribute to the degradation of the physical properties of the soil and threaten its fertility [5]. These data point to the existence of great opportunities for the exploitation of rural areas in order to develop tourism on farms. On the other hand, the events of the 1990s, migration from village to town, the economic crisis and other factors have influenced the economic extinction of Serbian villages. In an effort to identify the similarities and differences between the rural areas of Serbia, as well as their strengths and weaknesses, their typology has been developed [5]:

- Type 1: highly productive agriculture and integrated economy. This group of rural municipalities includes municipalities in Vojvodina and northern parts of Serbia around the Sava and Danube rivers. In these areas, the highly productive agriculture is presented with a better structure of households (households with more productive soils) and vertical integration with the agriculture and food sector. Also the services and industrial sectors in the context of Serbia are better developed here.

- Type 2: small urban economies with intensive work in agriculture. The cluster-region geographically extends through the rural municipalities along the river valley and is located on the main roads in Serbia, which has radial expansion from Belgrade to Montenegro, Bosnia and Macedonia. These areas were identified as the so-called urbanized villages, located close to major Serbian cities. Their intensive agricultural production is market-oriented, while their rural economy is diverse - developed services and small and medium-sized enterprises. 
- Type 3: predominantly mountainous economy is oriented to natural resources. This cluster-region includes the mountainous rural municipalities of Southeast Serbia. It is characterized by low population density and negative demographic changes. This economic structure has lower productivity in agricultural production, certain industrial activities, developed services and tourism potential. It is basically a rural region oriented toward natural resources, with unused natural resources and tourism potential, as well as the possibility of exploitation of rural benefits: natural resources, rural environment, cultural heritage.

- Type 4: large tourist facilities and poor agricultural structure. This cluster of rural municipality is located in the western part of Serbia, and has large touristic capacities. The index of the number of hotel rooms per 1,000 people in this cluster is three times higher than the national average. However, agricultural structures are the worst among all the types described herein.

The highlighted typology indicates the existence of opportunities for promotion of rural tourism development almost in all parts of Serbia to a greater or lesser extent. The economic importance of rural tourism is more than important for the revitalization of Serbian villages. In our country until 2012, 950 households were categorized engaged in this form of tourism. Totally about 300 households are engaged solely in tourism while on average from 750 to 1500 overnight stays are being realized per year per household [24]. According to the Master Plan for Sustainable Development of Rural Tourism of the Republic of Serbia, the following guidelines have been defined for positioning Serbia as a rural tourism destination [3]: development of a holistic experience in rural tourism, which consists of integrating rural activities, rural housing and development centers for activities, development of quality standards for products and services throughout the entire value chain so as to ensure that the rural activities, rural accommodation, activity centers and other services are in line with international quality standards, the development of a multi-layered approach to USP, development of an integrated operational marketing plan that supports communication and commercialization of rural tourism and allows the visitors/ tourists to pack their own experience of rural tourism, the establishment of service centers for development of human capacities, establishing a global system management, with special emphasis on children's and family tourism.

However, rural households are facing numerous problems in an effort to ensure all necessary conditions for providing services to tourists with limited financial resources to invest. In continuation, the emphasis is on good practices for rural tourism development while respecting the principles of sustainability.

Koštunići village is located on the slopes of Mount Suvobor and is the largest village in Gornji Milanovac by its surface $(4,736 \mathrm{ha})$. It is located $30 \mathrm{~km}$ from Gornji Milanovac. By its area of 4,736 ha, Koštunići is the largest village in the municipality of Gornji Milanovac. Through the village flow four mountain rivers Grab, Bukovača, Čemernica, Šiban, which are habitats of numerous species of river fish and crabs. This area is characterized by exceptional ecological and landscape values, such as the valley of mountain rivers and streams, with clear pronounced agrarian, forest and meadow ecosystems, rich with a variety of medicinal herbs, forest fruits. Koštunići has a mild and pleasant climate and has a good average annual temperature of $18^{\circ} \mathrm{C}$ degrees, with warmer autumn than spring season. Thanks to the preserved environment, this is the only ecological village in Serbia. In 1996, the ethno-project was launched with the aim of returning to healthy food, clean water and natural products. The plants were built there producing natural brandy, apple vinegar, herbs dryer, refrigerator for storing of raspberries, blackberries and berries. In the center of the village, ethno-complex Anđelija Mišić with ethno-house was built in, which holds the folklore of skilled weavers, embroiderers and yarn; apartment complex in the form of traditional wooden houses; ethnographic museum in which objects are kept by the people of this region used in the 18th and 19th centuries and a museum dedicated to Duke Živojin Mišić where twelve squares keep the relief space where Suvoborska battle occurred in the World War I [26]. This complex is an example of good practice in terms of unifying the offer in the form of traditional ecologically produced products, folk art and cultural and historical heritage.

Zlakusa is an example of the village, which seeks primarily socio-cultural sustainability through preservation of national creativity and presenting the same to tourists. It is located in western Serbia, in Zlatibor district and belongs to the territory of Užice, the headquarters of this tourist region. This village is known for its pottery craft. The tourist offer of this village includes: Ethno park of Terzić garden, which dates from the early 20th century and is a typical farm from the vicinity of Užice, with old houses and garden; rural tourist households, which are equipped with 50 beds, which are categorized and supported by the launch of Homeland Ethno Association; footpaths, respectively 4 circular footpaths with a 
total length of $60 \mathrm{~km}$ linking the most important tourist facilities in Zlakusa and the environment and Potpeć cave, which is located in the village of Potpeć, Zlakuse village, $14 \mathrm{~km}$ from Uzice, and is one of the monumental pieces of nature [27] This village is an example of good practice regarding the design of the attractiveness of the destinations on the artistic value and preserve them in contact between locals and tourists.

Ethno village Latkovac was originated on the place of the hearth older more than two centuries. Two decades ago, this place became a tourist resort thanks to its untouched nature, mountain water, local food, etc. It is located $220 \mathrm{~km}$ from Belgrade and $3 \mathrm{~km}$ from Aleksandrovac. The hamlet consists of five houses, stables and a barn. For tourists especially interesting is the library with over 3,000 books and Echo shop, where one can find homemade products [25]. Combination of pristine nature and environmentally responsible food production is a key tourist attraction that would attract both domestic and foreign tourists. The holders of rural tourism in Serbia have to formulate an appropriate product to meet the tourist demand, which would be equally interesting to the younger and older population. Integration of such offers with the products of spa and wellness tourism could contribute to greater popularization of this kind of tourism in Serbia, and certainly stimulate the local and national economy, as well as the universal well-being of the local population.

\section{CONCLUSION}

In this paper, the authors have analyzed the resources of the Republic of Serbia, which can be used for development and improvement of sustainable rural tourism as well as examples of good practice, which are the holders of the tourism offer of the same. Rural areas in Serbia have potentional to develop tourism with the sustainable use of resources. The wealth of water, climate, clean air, natural environment, gastronomy, as well as the traditions and culture of the rural households are comparative advantages for responsible development of rural tourism. In addition, rural tourism based on the principles of sustainability does not only mean the responsible use of natural resources in the long run, but also organic food production, which is part of the village's offer and can be commercialized through tourism.

The problems with which the villages are facing can be overcome by the development of rural tourism on the basis of sustainable production, the traditional way of doing business and the inclusion of local people in the process of providing services to tourists. In further development, destination management must focus their attention towards integrated planning of resource use with defining a framework for the application of sustainable development principles. Bearing in mind that tourists are increasingly more directed towards natural ambient, rural areas are gaining in importance as a destination where tourists spend their holidays. However, it is very important to raise the awareness of all participants of rural tourism on the necessity of responsible behavior towards natural resources which represent the resources for their further development. All participants of this form of tourism should be aware of their roles and responsibilities in the development of rural tourism in compliance with the principles of sustainability.

\section{REFERENCE}

[1] Borto, G. (2002). Rural Tourism in Romania - Characteristics ande trends. Tourism, Journal of Department of Geography, Tourism and Hotel Management, Faculty of Sciences. Vol. 6, pp. 111-113.

[2] Bošković, T. (2008). Održivi turizam kao savremeni koncept razvoja. Business School. Vol. 4, pp. 123127.

[3] Common UN Programme on Sustainable Tourism for Rural Development. (2011). Master Plan for Sustainable Development of Rural Tourism of the Republic of Serbia: Serbia.

[4] Čomić, Đ., \& Pjevač, N. (1997). Turistička geografija. Federal Centre for Improvement of the Hospitality: Belgrade.

[5] Đorđević Milošević, S., \& Milovanović, J. (2012). Održivi turizam u funkciji ruralnog razvoja. Faculty of Applied Ecology Futura, Singidunum University: Belgrade Agro-knowlede: Vrsac, FAO: Budapest.

[6] Fleischer, A., \& Pizam, A. (1997). Rural tourism in Israel. Tourism Management, Vol. 18 (6), pp. 367372.

[7] Gerritsen, P.R.W. (2014). Working with indigenous women on multifunctionality and sustainable rural tourism in western Mexico. The Journal of Rural and Community Development. Vol. 9 (3), pp. 243--257, 2014.

[8] Jelinčić, A. (2007). Agroturizam u europskom kontekstu. Studia ethnologica Croatica. Vol. 19 (1), pp. 269-291.

[9] Jovanović, V., \& Manić, E. (2012). Evaluation of sustainable rural tourism development in Serbia. Scientific Annals of the Danube Delta Institute. Vol 18 (1), pp. 285 - 294. DOI: 10.7427/DDI.18.19. 
[10] Kušen, E. (2007). Kako ugostiti turiste na vlastitom imanju. Institute for Tourism: Zagreb.

[11] Lane, B. (1994). Sustainable Rural Tourism Strategies: A Tool for Development and Conservation. Journal of Sustainable Tourism. Vol 2 (1 \& 2), pp. 102-111. DOI: $10.1080 / 09669589409510687$.

[12] Maksin, M., Pucar, M., Miljić, S., \& Korać, M. (2011). Održivi razvoj turizma u Evropskoj Uniji i Srbiji. Institute of Architecture and Urban \& Spatial Planning of Serbia: Belgrade.

[13] Midlleton, T.C.V. (1982). Tourism in rural areas. Tourism Management, Amsterdam, Vol. 3 (1), pp. 52-58. DOI: 10.1016/0261-5177(82)90026-7.

[14] Ministry of Agriculture, Forestry and Water Management. (2007). Mala ruralna domaćinstva u Srbiji i ruralna nepoljoprivredna ekonomija The United Nations Development Programme: Belgrade.

[15] Muhi, B. (2010). Ruralni turizam kao faktor revitalizacije sela u Vojvodini - izazovi i pravci razvoja. Economics of Agriculture. Vol. 57 (3), pp. 475-485.

[16] Perales, BY. (2002). Rural tourism in Spain. Annals of Tourism Research. Vol. 29. (4), pp. 1101-1110.

[17] Sillignakis, K. (2001). Rural tourism: An opportunity for sustainable development of rural areas. available at: www.sillignakis.com/PDF/Rural_Tourism_ Finall_ALL.pdf.
[18] Štetić, S., \& Šimičević D. (2008). How to develop sustainable tourism in rural destinations in Serbia. Bulletin of the Serbian Geographical Society. 88(4), pp. 19-28. DOI:10.2298/ GSGD0804019S.

[19] Todorović, M., \& Bljejac, Ž. (2007). Osnove razvoja ruralnog turizma u Srbiji. Bulletin of the Serbian Geographical Society. LXXXVII, br.1, pp. 135-148.

[20] Vuković, P., Arsić, S., Cvijanović, D. (2012). Konkurentnost ruralnih turističkih destinacija. Economics of Agriculture. Vol. 57, (1), pp. 47-60.

[21] Weaver, D. (2006). Sustainable Tourism: Theory and Practise. Butterwort-Heinemann: Oxford.

[22] http://sdt.unwto.org/. Retrieved date of access (22.02.2016.)

[23] http://www.cenort.rs/?page_id=78. Retrieved date of access (22.02.2016.)

[24] http://www.selo.rs/RS/za-domacine. Retrieved date of access (25.02.2016.)

[25] http://ethno.co.rs/. Retrieved date of access (25.02.2016.)

[26] http://www.togm.org.rs/turisti\%C4\%8Dkaponuda/ destinacije/ko\%C5\%A1tuni\%C4\%87i.html. Retrieved date of access (27.02.2016.)

[27] http://www.zlakusa.com/. Retrieved date of access (01.03.2016.) 